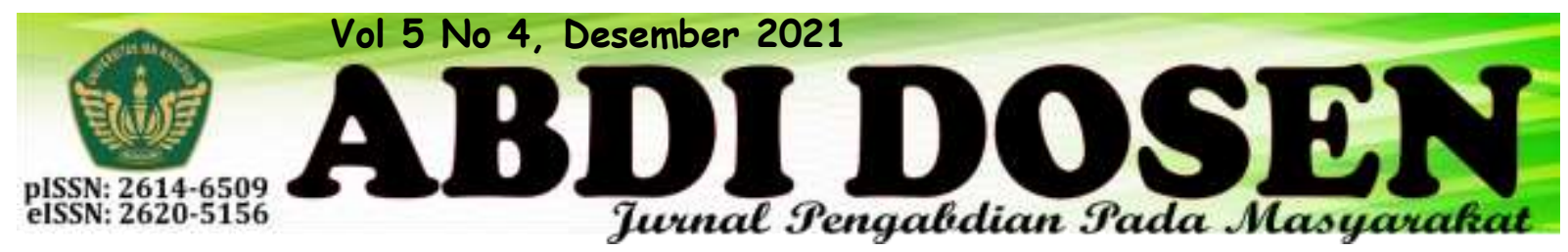

\title{
PELATIHAN PENYUSUNAN PERANGKAT PEMBELAJARAN BDR BAGI GURU PENDIDIKAN ANAK USIA DINI DI KOTA JAYAPURA
}

\author{
Sirjon $^{1}$, Diana Setyaningsih ${ }^{2}$, Erna Olua $^{3}$, Andrianus Krobo ${ }^{4}$ \\ sirjon@fkip.uncen.ac.id ${ }^{1 *}$ \\ diananing24@gmail.com ${ }^{2}$ \\ erna.olua@gmail.com ${ }^{3}$ \\ krobozon@gmail.com ${ }^{4}$ \\ Universitas Cenderawasih ${ }^{1,2,3,4}$
}

\begin{abstract}
This community service activity is a training "Development of BDR Learning Tools for PAUD Teachers" in Jayapura City. This activity was carried out for PAUD teachers in Jayapura City. The number of targets who attended the activity was 23 teachers. The purpose of this activity is to facilitate and provide training to PAUD teachers in Jayapura City to be able to develop BDR learning tools and the ability to choose and determine the right media in BDR learning. This method is in the form of lectures and questions and answers as well as direct practice (demonstration). The results of the evaluation of community service on training in the preparation of BDR learning tools for PAUD teachers in Jayapura City were declared successful. This can be seen from the evaluation results, from 23 participants there were 20 participants (86.96\%) in the very good category and 2 participants $(8.69 \%)$ in the good category and 1 participant (4.35\%) in the good category. pretty good category. . In other words, this training has been successful and can improve the knowledge, insight, understanding, and skills of participants in developing BDR learning tools and choosing the right BDR learning media.
\end{abstract}

Keywords: Learning from Home; Teacher; Learning Media.

\begin{abstract}
ABSTRAK
Kegiatan pengabdian kepada masyarakat ini berjudul pelatihan "Penyusunan Perangkat Pembelajaran BDR (Belajar Dari Rumah) Bagi Guru Pendidikan Anak Usia Dini” di Kota Jayapura. Kegiatan tersebut dilaksanakan bagi Guru PAUD yang ada di Kota Jayapura. Jumlah sasaran yang menghadiri kegiatan adalah 23 orang Guru. Tujuan dilaksanakannya kegiatan ini adalah untuk memfasilitasi dan memberikan pelatihan kepada Guru PAUD yang ada di Kota Jayapura untuk dapat menyusun perangkat pembelajaran BDR serta kemampuan memilih dan menentukan media yang tepat dalam pembelajaran BDR. Metode kegiatan ini adalah ceramah dan tanya jawab serta praktek langsung (demonstrasi). Hasil evaluasi dari kegiatan pengabdian kepada masyarakat tentang pelatihan penyusunan perangkat pembelajaran BDR bagi guru PAUD di Kota Jayapura ini dinyatakan berhasil dengan baik. Hal ini dapat dilihat dari hasil evaluasi bahwa, dari 23 peserta terdapat 20 peserta $(86,96 \%)$ yang termasuk kategori sangat baik dan 2 peserta $(8,69 \%)$ termasuk kategori baik dan 1 peserta $(4,35 \%)$ termasuk kategori cukup baik. Dengan kata lain, pelatihan ini telah berhasil
\end{abstract}


dengan baik dan dapat meningkatkan pengetahuan, wawasan, pemahaman, dan keterampilan peserta dalam menyusun perangkat pembelajaran BDR dan memilih media pembelajaran BDR yang tepat.

\section{Kata kunci: Belajar dari Rumah; Guru; Perangkat Pembelajaran}

\section{PENDAHULUAN}

Masa usia dini merupakan masa keemasan anak yang juga disebut dengan istilah golden age. Pada masa ini kemampuan anak untuk menyerap informasi yang diterimanya sangat tinggi, sehingga menjadi fase yang tepat dalam mengembangkan aspek-aspek perkembangan anak. Dalam upaya mengembangkan berbagai aspek perkembangan tersebut, guru dihadapkan dengan berbagai persoalan pembelajaran akibat munculnya pandemi Covid-19. Munculnya covid-19 membuat berbagai perubahan, namun persiapan untuk menghadapi berbagai perubahan tersebut belum maksimal (Daheri, Juliana, Deriwanto, \& Amda, 2020). Oleh karenanya, diperlukan kebijakan-kebijakan yang tepat untuk menghadapi kondisi tersebut. Pandemi covid-19 kemudian memaksa pemerintah melalui Kementerian Pendidikan dan Kebudayaan mengeluarkan Surat Edaran Kemendikbud Nomor 4 Tahun 2020. Surat edaran tersebut menyatakan bahwa proses pembelajaran dilaksanakan secara daring atau jarak jauh dari rumah untuk tetap memberikan pembelajaran yang bermakna bagi peserta didik (Indonesia, 2020a). Salah satu bentuk pembelajaran daring adalah e-learning. Menurut (Hutami \& Nugraheni, 2020), elearning merupakan proses pembelajaran dengan memanfaatkan perangkat elektronik. E-learning juga sering dikaitkan dengan program pendidikan mandiri. Menurut (Mutaqinah \& Hidayatullah, 2020), program pendidikan mandiri merupakan proses belajar (membaca dan menelaah serta memahami pengetahuan) baik dalam lingkungan sekolah maupun diluar sekolah. E-learning dilaksankan dalam pembelajaran BDR yang menuntut pemanfaatan teknologi informasi. Oleh karena itu, pelaksanaan BDR mengharuskan guru untuk dapat menggunakan teknologi dalam proses pembelajarannya. Pemanfaatan teknologi teknologi tersebut akan menunjang terjadinya proses belajar mengajar ditengah pandemi covid-19 (Astini, 2020). Sistem pembelajaran daring berbasis teknologi informasi akan dapat memenuhi kebutuhan belajar peserta didik serta keluasan jangkauannya diharapkan dapat mempermudah akses informasi dan pembelajaran secara cepat dan efektif (Arifin, 2020). (Kurniasari, Pribowo, \& Putra, 2020) menambahkan bahwa salah satu prinsip dari Kegiatan BDR adalah mempermudah peserta didik dalam mengakses konten (materi) dan sumber belajar. Pembelajaran daring tersebut akan berhasil, apabila sarana dan prasarana tersedia dan memadai seperti kesiapan SDM, teknologi (smartphone atau laptop), jaringan internet, serta kuota/data, dan listrik (Nirmala \& Annuar, 2021). Jika sarana dan prasarana tersebut tersedia, maka pembelajaran akan dapat mencapai tujuan (hasil) secara efektif.

Keberhasilan pelaksanaan BDR tidak hanya menjadi tanggung jawab guru secara personal, melainkan kolaborasi aktif diantara guru dan orang tua (Sarjono, 
2020). Hal ini sesuai dengan pendapat (Suasthi \& Suadnyana, 2020) yang mengemukakan bahwa pembelajaran BDR mendorong kolaborasi orangtua, guru, dan peserta didik dalam menerapkan pembelajaran yang bermakna. Peran pendamping (orang tua) akan berjalan seiring dengan peran guru sehingga tujuan pembelajaran yang ditetapkan dapat diperoleh dengan baik (Erni, Yasnel, Roza, Yola, \& Salmiah, 2020). Proses pembelajaran BDR seyogianya tetap dapat mengembangkan bakat dan minat peserta didik (Wibowo, Deta, \& Dores, 2020). Oleh karenanya, pembelajaran harus diarahkan pada ketercapaian tujuan pembelajaran yang ditetapkan. Hal ini sejalan dengan pendapat (Kurniasari et al., 2020) yang menyatakan bahwa tujuan pembelajaran harus menjadi perhatian utama dalam pelaksanaan pembelajaran baik secara online maupun offline. (Wibowo et al., 2020) menambahkan bahwa dalam efektivitas pembelajaran harus menjadi perhatian serius dalam setiap proses pembelajaran yang dilaksanakan. (Iftitah \& Anawaty, 2020) mengemukakan bahwa besarnya atensi peserta didik terhadap pembelajaran daring akan sangat bergantung pada kreativitas guru dalam merencanakan pembelajarannya. Oleh karenanya, dalam upaya mencapai tujuan pembelajaran yang dimaksud, dibutuhkan kreativitas dari guru dalam penyelenggaraan pembelajaran BDR. Kreativitas yang dimaksud termasuk dalam penyusunan perangkat pembelajaran BDR, penentuan model/metode serta media pembelajaran yang dapat menunjang pencapaian tujuan pembelajaran. Model pembelajaran yang diterapkan pada pembelajaran BDR harus dapat memfasilitasi gaya belajar masing-masing anak (Hariyani, 2020). Penentuan model pembelajaran yang akan diterapkan tetap harus memperhatikan tujuan dan materi serta situasi dan kondisi yang terjadi di Sekolah (Jayul \& Irwanto, 2020). Sejalan dengan pendapat tersebut (Dewi, 2020) mengemukakan bahwa keberhasilan penerapan suatu model atau media pembelajaran akan sangat dipengaruhi oleh karakteristik peserta didiknya. Adapun media pembelajaran yang dapat digunakan dalam pembelajaran $\mathrm{BDR}$ seperti google classroom, zoom, google meet, telepon atau whatsapp dan lain-lain (Dewi, 2020). Selain media pembelajaran di atas, pendidik juga dapat menggunakan edutainment atau game edukasi (Pratama, Lestari, \& Astutik, 2020). Komunikasi dengan orang tua dan peserta didik, dapat menggunakan whatsapp group sebagai alternatif media komunikasi, karena menurut (Hutami \& Nugraheni, 2020), penggunaannya mudah dan fleksibel.

Proses pendidikan memiliki peran sentral dalam upaya pengembangan seluruh potensi dan keterampilan peserta didik secara optimal. Oleh karenanya pendidikan harus diberikan sejak anak usia dini sehingga kemampuan serta keterampilan individu dapat dikembangkan secara optimal. Pembelajaran harus didesain atau dirancang agar dapat meningkatkan kualitas pembelajaran. Barometer kualitas pembelajaran dapat dilihat dari sejauh mana suatu kegiatan pembelajaran dapat mengubah tingkah laku peserta didik (Direktorat Pembinaan Pendidikan Anak Usia Dini, 2018). Oleh karenanya, pembelajaran harus senantiasa berorientasi pada pencapaian tujuan pembelajaran. Pembelajaran pada masa pandemi covid-19 memberikan tantangan tersendiri bagi peserta didik dan guru (Subekti \& Kurniawati, 2020). Guru dituntut untuk memiliki kemampuan dalam 
membuat perangkat pembelajarannya, seperti yang dikemukakan oleh (Nuris, Suparti, \& Sulastri, 2018) bahwa seluruh aspek perkembangan anak dapat dikembangkan melalui perencanaan yang matang sehingga anak dapat terlibat secara aktif dalam pembelajaran. Oleh karenanya, guru perlu merancang suatu perangkat pembelajaran seperti silabus, RPPH/RPPM, bahan ajar, dan media pembelajaran. Untuk menerapkan model, metode, media dan perangkat pembelajaran yang lain dalam upaya pencapaian tujuan pembelajaran yang ditetapkan, maka diperlukan suatu perencanaan yang tepat dan maksimal. Oleh karenanya, guru wajib melakukan perencanaan pembelajaran BDR agar semua kegiatan pembelajaran yang diterapkan diorientasikan pada pencapaian tujuan pembelajaran. Perencanaan pembelajaran dilaksanakan dengan tujuan untuk membantu pencapaian tujuan pembelajaran secara efektif (Indonesia, 2020b). Perencanaan pembelajaran harus terus dilakukan oleh guru setiap waktu.

Penerapan BDR secara otomatis memberikan tuntutan kepada Guru untuk

\section{METODE PELAKSANAAN}

Kegiatan ini menggunakan metode ceramah, tanya jawab dan praktek langsung (demonstrasi). Ceramah digunakan untuk menyampaikan materi secara teoris dan tanya jawab digunakan untuk memperoleh umpan balik dari sasaran dan untuk memperoleh gambaran tentang pemahaman materi oleh sasaran. Sedangkan metode praktek langsung (demonstrasi) digunakan sebagai cara untuk menunjukkan keterampilan sasaran dalam membuat perangkat pembelajaran BDR serta memilih media pembelajaran yang tepat. dapat memilih materi-materi esensial. Dalam merancang pembelajaran BDR, guru diwajibkan untuk membuat perangkat pembelajaran sehingga BDR yang dilaksanakan dapat mencapai tujuan pembelajaran yang diharapkan. Berdasarkan analisis situasi yang dilakukan terhadap guru PAUD di Kota Jayapura, diperoleh fakta bahwa masih banyak guru yang merasa kesulitan untuk menyiapkan perangkat pembelajaran BDR. Selain itu, banyak guru yang masih bingung untuk memilih media yang tepat untuk mendukung pelaksanaan pembelajaran BDR. Hasil analisis situasi tersebut di atas, mendorong pengabdi untuk melakukan kegiatan pengabdian kepada masyarakat yang berjudul Pelatihan "Penyusunan Perangkat Pembelajaran BDR (Belajar Dari Rumah) Bagi Guru Pendidikan Anak Usia Dini" di Kota Jayapura sebagai alternatif solusi terhadap permasalahan yang dihadapi oleh guru. Komunitas sasaran yang dilibatkan dalam kegiatan ini adalah guru PAUD di Kota Jayapura yang tersebar di beberapa wilayah. Jumlah sasaran yang menghadiri kegiatan sebanyak 23 orang guru.

Pelaksanaan evaluasi untuk menyatakan keberhasilan kegiatan ini, dilaksanakan pada proses dan akhir pelatihan. Pada proses pelatihan dilakukan evaluasi terhadap kemampuan sasaran dalam menyusun RPM pembelajaran BDR. Sedangkan pada akhir kegiatan evaluasi dilakukan terhadap kemampuan menentukan media pembelajaran sesuai dengan skenario pembelajaran yang telah ditetapkan. Adapun indikator penilaian dalam kegiatan ini adalah: 
Tabel 1. Instrumen Evaluasi

\begin{tabular}{|c|c|c|c|}
\hline No & $\begin{array}{c}\text { Aspek/ } \\
\text { Kemampuan } \\
\text { yang dinilai }\end{array}$ & Indikator & Skor \\
\hline \multirow[t]{7}{*}{1} & \multirow[t]{7}{*}{ Membuat RPM } & $\begin{array}{l}\text { 1) Kesesuaian antara bahan pembelajaran dengan } \\
\text { kurikulum sekolah }\end{array}$ & $\begin{array}{lllll}1 & 2 & 3 & 4 & 5\end{array}$ \\
\hline & & 2) Kejelasan tujuan pembelajaran & $\begin{array}{lllll}1 & 2 & 3 & 4 & 5\end{array}$ \\
\hline & & 3) Kejelasan materi & 123345 \\
\hline & & 4) Ketepatan metode yang digunakan & 1223045 \\
\hline & & $\begin{array}{l}\text { 5) Kesesuaian media pembelajaran dengan tujuan } \\
\text { pembelajaran }\end{array}$ & $\begin{array}{lllll}1 & 2 & 3 & 4 & 5\end{array}$ \\
\hline & & 6) Kejelasan kegiatan pembelajaran di Rumah & $\begin{array}{lllll}1 & 2 & 3 & 4 & 5\end{array}$ \\
\hline & & 7) Kesesuaian antara tujuan, metode dan penilaian & 1223045 \\
\hline \multirow[t]{4}{*}{2} & \multirow[t]{4}{*}{$\begin{array}{l}\text { Pemilihan media } \\
\text { pembelajaran }\end{array}$} & $\begin{array}{l}\text { 8) Kesesuaian media pembelajaran dengan tujuan } \\
\text { pembelajaran }\end{array}$ & 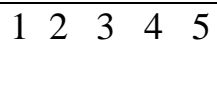 \\
\hline & & $\begin{array}{l}\text { 9) Kemudahan orangtua dalam menyiapkan media } \\
\text { pembelajaran di Rumah }\end{array}$ & 1223345 \\
\hline & & $\begin{array}{l}\text { 10) Kesesuaian antara media pembelajaran dengan } \\
\text { karakteristik anak }\end{array}$ & $\begin{array}{lllll}1 & 2 & 3 & 4 & 5\end{array}$ \\
\hline & & 11) Keamanan media pembelajaran yang dipilih & $\begin{array}{lllll}1 & 2 & 3 & 4 & 5\end{array}$ \\
\hline
\end{tabular}

Jumlah indikator dalam penilaian ini adalah 11 butir, masing-masing indikator diberi skor 1 sampai 5 sehingga total skor yang diperoleh minimal 11 dan maksimal 55. Pengisian penilaian dilakukan dengan melingkari skor penilaian pada setiap indikator. Hasil penilaian setiap individu, dihitung dari total skor yang diperoleh. Kegiatan pelatihan dinyatakan berhasil apabila minimal $80 \%$ dari jumlah sasaran Masuk dalam kategori penilaian Baik. Kriteria Penilaian yang digunakan adalah:

Tabel 2. Kriteria Penilaian

\begin{tabular}{|c|l|c|}
\hline No & Kriteria Penilaian & Total Skor \\
\hline 1 & Sangat baik & $87-100$ \\
\hline 2 & Baik & $69-86$ \\
\hline 3 & Cukup baik & $53-68$ \\
\hline 4 & Kurang baik & $37-52$ \\
\hline 5 & Sangat tidak baik & $20-36$ \\
\hline
\end{tabular}

\section{HASIL dan PEMBAHASAN}

Kegiatan ini dinilai berhasil apabila berjalan sesuai dengan rencana yang sudah dipersiapakan dan tepat waktu serta tepat sasaran dan tujuan yang sudah ditetapkan.
Untuk menentukan tingkat keberhasilan kegiatan, maka dilakukan evaluasi dengan berbagai cara, yaitu tanya jawab untuk mengetahui tingkat pemahaman peserta 
tterhadap konsep dan perangkat pembelajaran BDR. Evalusi dilakukan melalui observasi atau pengamatan terutama selama kegiatan berlangsung untuk mengetahui animo dan partisipasi aktif peserta selama kegiatan berlangsung. Hasil evaluasi yang dilakukan ini akan menggambarkan tentang daya serap, pemahaman serta ketrampilan yang mereka peroleh serta manfaat atau nilai tambah setelah mereka mengikuti kegiatan ini. Kegiatan dimulai dengan pemaparan materi oleh pemateri pertama yang membawakan materi tentang konsep pembelajaran BDR (Belajar Dari Rumah).

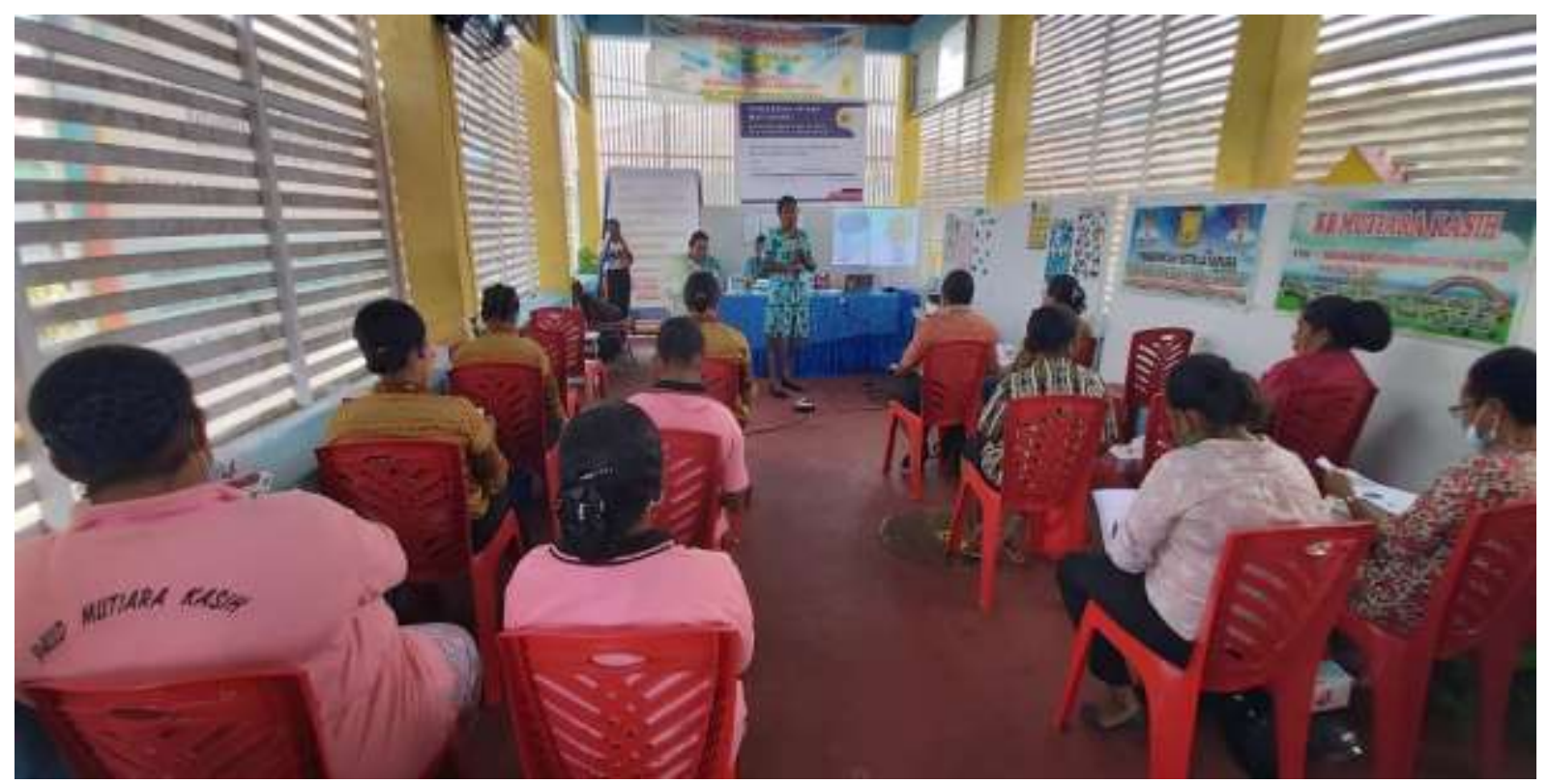

Gambar 1. Pemaparan Materi Oleh Pemateri Pertama

Selanjutnya, kegiatan dilanjutkan dengan pemaparan materi tentang penyusunan perangkat pembelajaran BDR (Konsep dan Praktek).

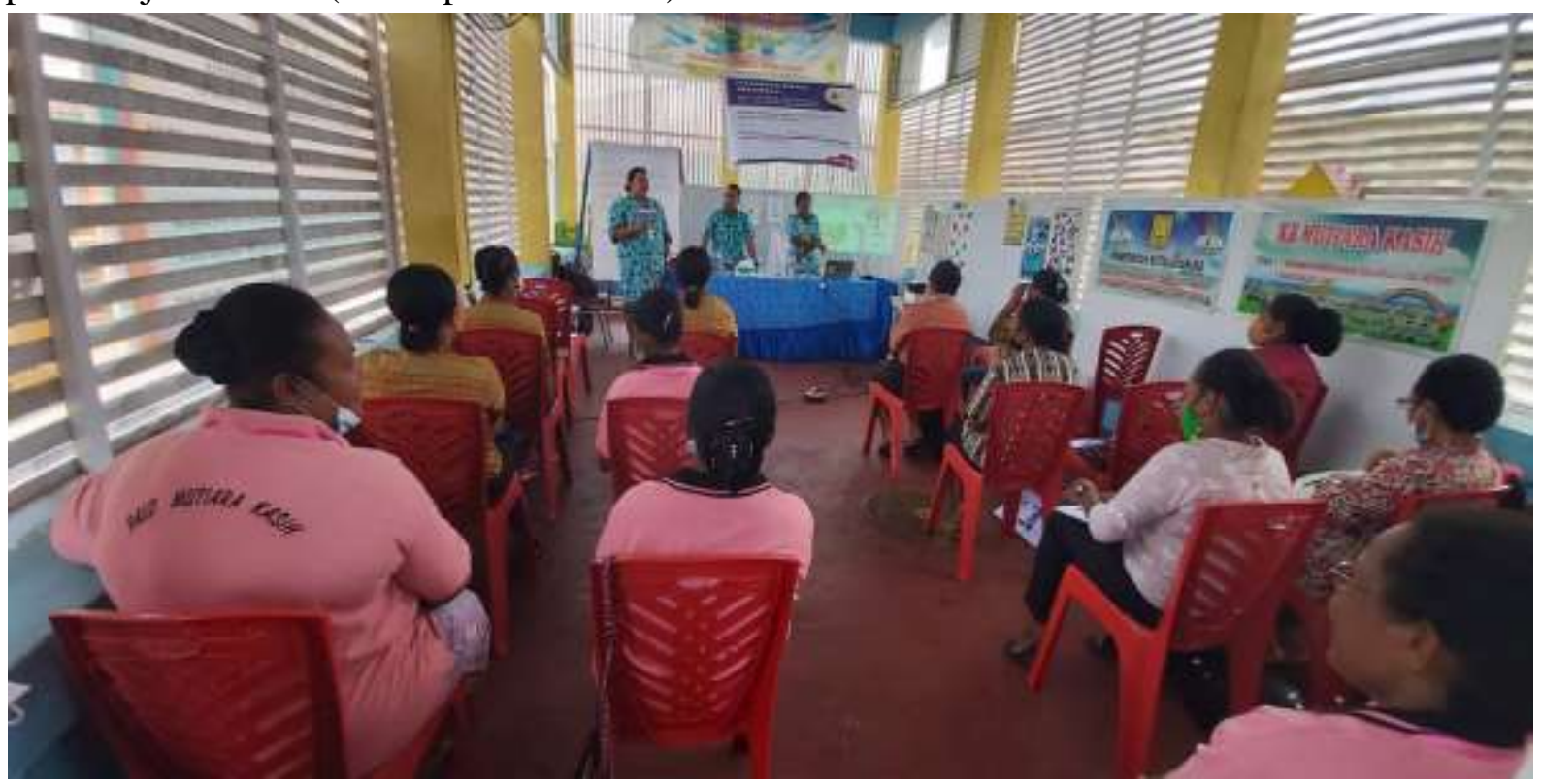

Gambar 2. Pemaparan Materi Oleh Pemateri Kedua dan Ketiga 
Kegiatan selanjutnya, diisi dengan pemaparan materi tentang penilaian oleh pemateri keempat.

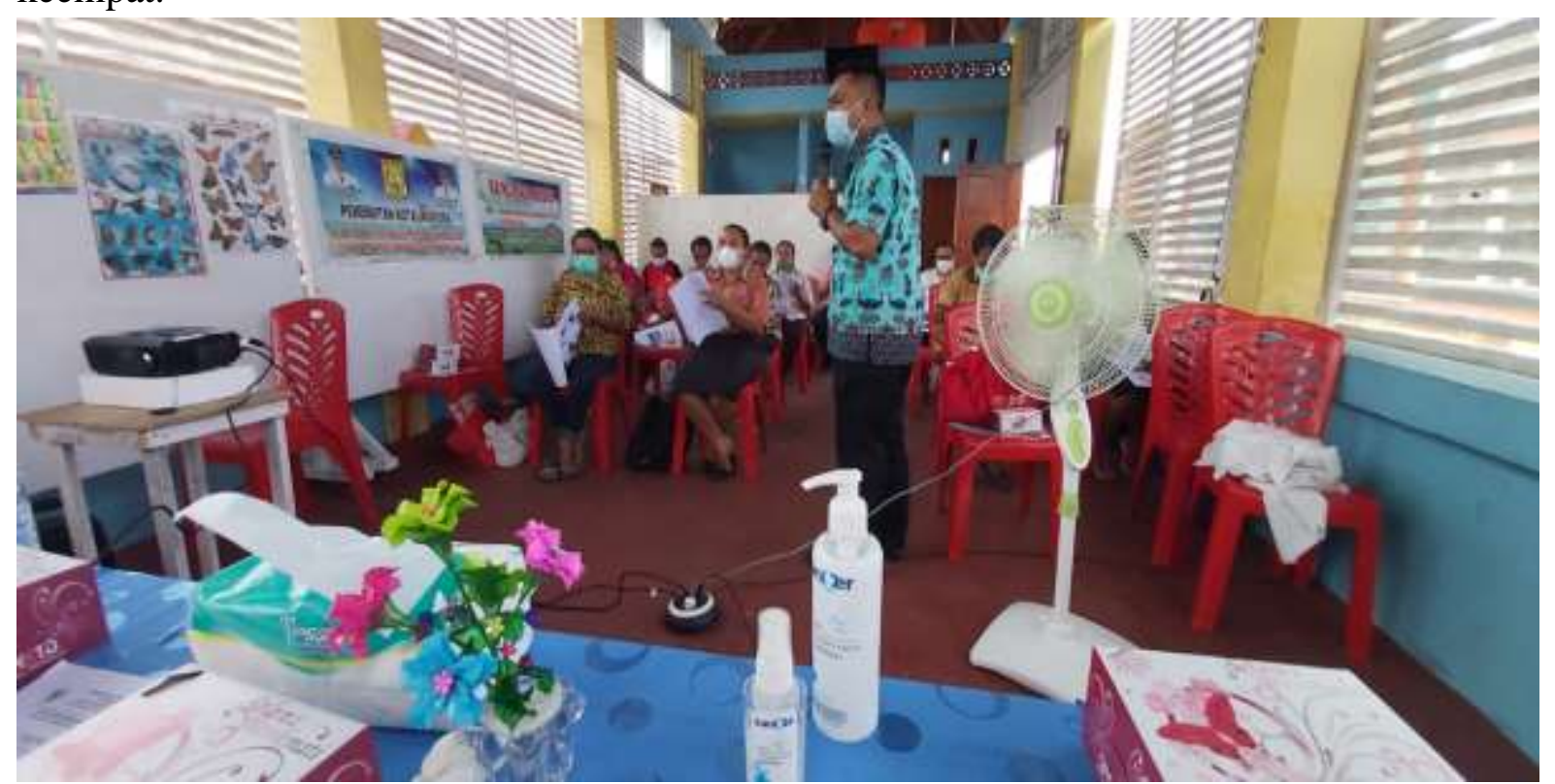

Gambar 3. Pemaparan Materi Oleh Pemateri Keempat

Pada akhir kegiatan, peserta menyampaikan pesan dan kesan terhadap kegiatan yang sudah dilaksanakan. Berdasarkan pesan dan kesan yang disampaikan oleh peserta yang mewakili peserta kegiatan ini, diperoleh kesan bahwa mereka sangat senang dalam mengikuti kegiatan dan menyatakan kegiatan ini sangat bermanfaat pada pelaksanaan pembelajaran selama pandemi covid-19 belum berakhir. Adapun faktor pendukung yang menunjang kegiatan ini antara lain : 1) Sambutan yang sangat baik dan positif dari Kepala Sekolah PAUD Mutiara Kasih Tanjung Ria Jayapura terhadap rencana kegiatan yang dilaksanakan. Kepala Sekolah dengan senang hati menyatakan sendiri kesediaannya untuk mengundang guruguru PAUD yang dilibatkan dalam kegiatan ini; 2) Minat yang tinggi untuk mengikuti kegiatan. Hal ini ditunjukkan bahwa semua peserta yang hadir dengan setia mengikuti kegiatan dari awal kegiatan hingga selesai; 3) Kepala Sekolah PAUD Mutiara Kasih menyediakan ruangan/tempat untuk pelaksanaan kegiatan; 4) Tim dosen selain membagikan alat protokol kesehatan juga membagikan fotocopy materi kepada semua peserta, sehingga selain menyimak dan memperhatikan penjelasan tim melalui materi yang ditayangkan dalam slide, peserta juga dapat mempelajari kembali materi yang sudah dibagikan. Adapun faktor penghambat dari kegiatan ini adalah sulitnya komunikasi akibat adanya gangguan jaringan internet di Kota Jayapura, baik sebelum maupun setelah kegiatan dilaksanakan.

Berdasarkan kriteria penilaian di atas, dari 23 peserta yang hadir diperoleh hasil kegiatan sebagai berikut : 
Tabel 3. Hasil Penilaian

\begin{tabular}{|c|l|c|c|}
\hline No & \multicolumn{1}{|c|}{ Kriteria Penilaian } & f & Presentase (\%) \\
\hline 1 & Sangat tidak baik & 0 & 0 \\
\hline 2 & Kurang baik & 0 & 0 \\
\hline 3 & Cukup baik & 1 & 4,35 \\
\hline 4 & Baik & 2 & 8,69 \\
\hline 5 & Sangat baik Jumlah & 20 & 86,96 \\
\hline \multicolumn{2}{|c|}{$\mathbf{2 3}$} & $\mathbf{1 0 0}$ \\
\hline
\end{tabular}

Hasil kegiatan pada tabel 3, menunjukkan bahwa dari 23 peserta terdapat 20 peserta $(86,96 \%)$ yang termasuk kategori sangat baik dan 2 peserta $(8,69 \%)$ termasuk kategori baik

\section{KESIMPULAN}

Merujuk pada hasil evaluasi yang telah diuraikan sebelumnya, disimpulkan bahwa : 1) Kegiatan pengabdian kepada masyarakat tentang pelatihan penyusunan perangkat pembelajaran BDR bagi guruguru PAUD di Kota Jayapura ini dinyatakan berhasil dengan baik. Hal ini terbukti dari hasil evaluasi bahwa, dari 23 peserta terdapat 20 peserta $(86,96 \%)$ yang termasuk kategori sangat baik dan 2 peserta $(8,69 \%)$ termasuk kategori baik dan 1 peserta $(4,35 \%)$ termasuk kategori cukup baik. Dengan kata lain, pelatihan ini telah berhasil dengan baik dan dapat meningkatkan pengetahuan/pemahaman, serta keterampilan peserta dalam menyusun perangkat pembelajaran BDR dan memilih media pembelajaran BDR yang tepat; 2) Peserta pada umumnya dan 1 peserta $(4,35 \%)$ termasuk kategori cukup baik. Dengan demikian, kriteria keberhasilan kegiatan pengabdian kepada masyarakat yang ditetapkan telah tercapai dengan sangat baik.

memberikan respons positif terhadap kegiatan ini dan mengharapkan ada kegiatan-kegiatan serupa untuk waktu mendatang. Mengingat besarnya manfaat kegiatan ini bagi guru PAUD untuk meningkatkan profesionalisme mereka, maka diharapkan ada kegiatan pelatihanpelatihan atau workshop secara berkelanjutan untuk membina dan mengembangkan profesionalisme guru PAUD dalam melaksanakan tugasnya. Bila memungkinkan kegiatan ini dapat dilaksanakan di daerah-daerah lain dalam rangka membina dan mengembangkan profesionalisme guru dalam melaksanakan tugasnya terutama pada masa pandemi covid-19 dimana pembelajaran dilaksanakan dari rumah. 


\section{DAFTAR PUSTAKA}

Arifin, A. S. (2020). Persepsi Guru Madrasah Ibtidaiyah terhadap Pembelajaran Daring Selama Program Belajar dari Rumah ( BDR ) di Masa Pandemi COVID-19. Jurnal Literasi, $X I(2), \quad 150-158$. Retrieved from https://ejournal.almaata.ac.id/index.ph p/LITERASI/article/view/1430

Astini, N. K. S. (2020). Pemanfaatan Teknologi Informasi dalam Pembelajaran Tingkat Sekolah Dasar pada Masa Pandemi Covid-19. Jurnal Lampuhyang, 11(2), 13-25. Retrieved from https://e-journal.stkipamlapura.ac.id/index.php/jurnallampu hyang

Daheri, M., Juliana, Deriwanto, \& Amda, A. D. (2020). Efektifitas WhatsApp sebagai Media Belajar Daring. Jurnal BASICEDU, 4(4), 775-783. http://doi.org/10.31004/basicedu.v4i4. 445

Dewi, W. A. F. (2020). Dampak Covid-19 Terhadap Implementasi Pembelajaran Daring di Sekolah Dasar. Edukatif: Jurnal Ilmu Pendidikan, 2(1), 55-61. http://doi.org/https://doi.org/10.31004 /edukatif.v2i1.89

Direktorat Pembinaan Pendidikan Anak Usia Dini, K. P. dan K. (2018). Penyusunan rencana pelaksanaan pembelajaran. Jakarta: Kementerian Pendidikan dan Kebudayaan.

Erni, S., Yasnel, Roza, E., Yola, M., \& Salmiah. (2020). Pendamping Belajar atau Guru Baru? Fenomena Aktifitas Ibu dalam Proses BDR Peserta didik SD Masa Pandemi Covid 19.
Marwah: Jurnal Perempuan, Agama Dan Jender, 19(2), 108-120. http://doi.org/10.24014/Marwah.v19i 2.11252

Hariyani, I. T. (2020). Pengembangan Model BDR (Belajar Di Rumah) Untuk Meningkatkan Inovatif Serta Kualitas Keterampilan AUD. Jurnal Lentera Anak, 01(01), 39-52. Retrieved from https://ejournal.unisnu.ac.id/jla/article /view/1503

Hutami, M. S., \& Nugraheni, A. S. (2020). Metode Pembelajaran Melalui Whatsapp Group Sebagai Antisipasi Penyebaran Covid-19 pada AUD di TK ABA Kleco Kotagede. Jurnal PAUDIA, 9(1), 126-130. http://doi.org/https://doi.org/10.26877 /paudia.v9i1.6107

Iftitah, S. L., \& Anawaty, M. F. (2020). Peran Orang Tua dalam Mendampingi Anak di Rumah Selama Pandemi Covid-19. Journal of Childhood Education, 4(2), 71-81. http://doi.org/https://doi.org/10.30736 /jce.v4i2.256

Indonesia. Surat Edaran Kemendikbud Nomor 4 Tahun 2020 tentang Pelaksanaan Kebijakan Pendidikan dalam Masa Darurat Penyebaran Corona Virus Disease (Covid-19) (2020). Indonesia.

Indonesia, K. P. dan K. R. (2020b). Rencana Pelaksanaan Pembelajaran. Jakarta: ementerian Pendidikan dan Kebudayaan Republik Indonesia. 
Jayul, A., \& Irwanto, E. (2020). Model Pembelajaran Daring Sebagai Alternatif Proses Kegiatan Belajar Pendidikan Jasmani di Tengah Pandemi Covid-19. Jurnal Pendidikan Kesehatan Rekreasi, 6(2), 190-199.

http://doi.org/10.5281/zenodo.389226 2

Kurniasari, A., Pribowo, F. S. P., \& Putra, D. A. (2020). Analisis Efektivitas Pelaksanaan Belajar Dari Rumah (BDR) Selama Pandemi Covid-19. Jurnal Review Pendidikan Dasar: Jurnal Kajian Pendidikan Dan Hasil Penelitian, 6(3), 246-253. http://doi.org/http://dx.doi.org/10.267 40/jrpd.v6n3.p246-253

Mutaqinah, R., \& Hidayatullah, T. (2020). Implementasi Pembelajaran Daring (Program BDR) Selama Pandemi Covid-19 di Provinsi Jawa Barat. Jurnal PETIK, 6(2), 86-95. Retrieved from

https://journal.institutpendidikan.ac.id /index.php/petik/article/view/869

Nirmala, B., \& Annuar, H. (2021). Home Visit: Strategi PAUD dari Rumah bagi Guru di Daerah 3T pada Masa Pandemi Covid-19. Jurnal Obsesi : Jurnal Pendidikan Anak Usia Dini, 5(2), 1052-1062. http://doi.org/10.31004/obsesi.v5i2.71 6

Nuris, D. M., Suparti, \& Sulastri. (2018). Pelatihan Penyusunan Perangkat Pembelajaran Berbasis TIK Bagi Guru Akuntansi SMK. Dinamisia: Jurnal Pengabdian Kepada Masyarakat, 2(2), 256-260. http://doi.org/10.31849/dinamisia.v2i 2.1819

Pratama, L. D., Lestari, W., \& Astutik, I. (2020). Efektifitas Penggunaan Media Edutainment di Tengah Pandemi Covid-19. Jurnal AKSIOMA, 9(2), 413-423.

http://doi.org/https://doi.org/10.24127 /ajpm.v9i2.2783

Sarjono. (2020). Penerapan Supervisi Akademik Pengawas Guna Meningkatkan Keterampilan Guru dalam Melaksanakan Program BDR (Belajar dari Rumah) Selama Masa Pandemi Covid-19 di Dabin 1 Korwilcam Bidang Pendidikan Kecamatan Sumowono. Jurnal Wawasan Pengembangan Pendidikan, 08(02), 54-60. Retrieved from

https://ejournal.undaris.ac.id/index.ph p/waspada/article/view/174

Suasthi, I. G. A., \& Suadnyana, I. B. P. E. (2020). Membangun Karakter “ Genius " Anak Tetap Belajar Dari Rumah Selama Pandemi Covid - 19 Pada Sekolah Suta Dharma Ubud Gianyar. Cetta: Jurnal Ilmu Pendidikan, 3(3), 431-451. Retrieved from http://jayapanguspress.penerbit.org/in dex.php/cetta/article/view/541 
Subekti, A. S., \& Kurniawati, L. A. (2020). Pelatihan Mendesain Pembelajaran Daring Menarik Selama Pandemi Covid-19 dengan Teknologi Pembelajaran Sederhana. Dinamisia: Jurnal Pengabdian Kepada Masyarakat, 4(4), 588-595. http://doi.org/10.31849/dinamisia.v4i
4.4679

Wibowo, D. C., Deta, Y., \& Dores, O. J. (2020). Efektivitas Belajar Dari Rumah di Tengah Pandemi Covid-19. Jurnal Pendidikan Dasar Perkhasa, $6(2)$, 228-241. http://doi.org/10.31932/jpdp.v6i2.893 